\title{
Lizards and snakes from the late Miocene hominoid locality of Ravin de la Pluie (Axios Valley, Greece)
}

\author{
Georgios L. Georgalis ${ }^{1,2} \cdot$ Jean-Claude Rage ${ }^{3} \cdot$ Louis de Bonis $^{4} \cdot$ George D. Koufos $^{5}$
}

\begin{abstract}
We here describe lizards and snakes from the late Miocene (MN 10) of Ravin de la Pluie, near Thessaloniki, Greece, a locality widely known for its hominoid primate Ouranopithecus macedoniensis. The new finds comprise two large-sized lizards (a probable anguine and a varanid) and two snakes (an elapid and a small-sized "colubrine"). Even if the material is represented by few specimens, this is the first record of squamates from the late Miocene MN 10 biozone of southeastern Europe and the third only for the whole continent. The importance of the varanid vertebrae for systematic attributions is discussed. The new varanid limb elements described herein rank among the few such specimens in the fossil record of monitor lizards. Judging from the new and previously published varanid appendicular material, we suggest that Neogene monitor lizards from Europe possessed comparatively short and robustly built limbs. Distinctive scars on one of the limb elements are interpreted as bite marks of a predator or scavenger, offering insights on the palaeoecology of the herpetofauna of the locality.
\end{abstract}

Keywords Squamata $\cdot$ Neogene $\cdot$ Greece $\cdot$ Biogeography $\cdot$ Taxonomy

\section{Abbreviations}

HNHM Hungarian Museum of Natural History, Budapest, Hungary

LGPUT Laboratory of Geology and Palaeontology of the University of Thessaloniki, Thessaloniki, Greece

MDHC Massimo Delfino herpetological collection, Department of Earth Sciences of the University of Torino, Torino, Italy

Georgios L. Georgalis

georgios.georgalis@unifr.ch

1 Department of Geosciences, University of Fribourg, Chemin du Musée 6, 1700 Fribourg, Switzerland

2 Department of Earth Sciences, University of Torino, Via Valperga Caluso 35, 10125 Turin, Italy

3 Sorbonne Universités, CR2P, UMR 7207 CNRS-MNHNUPMC, Muséum national d'Histoire naturelle, CP 38, 57 rue Cuvier, 75231 Paris Cedex 05, France

4 Institut de paléoprimatologie, paléontologie humaine : évolution et paléoenvironnements-IPHEP, Université de Poitiers, 6 rue Michel Brunet, 86022 Poitiers Cedex, France

5 Laboratory of Geology and Paleontology, Department of Geology, Aristotle University of Thessaloniki, 54124 Thessaloniki, Greece
MNCN Museo Nacional de Ciencias Naturales, Madrid, Spain

MNHN Muséum national d'Histoire naturelle, Paris, France

NHMW Naturhistorisches Museum Wien, Vienna, Austria

RPl Ravin de la Pluie locality, Greece

ZZSiD Institute of Systematics and Evolution of Animals, Polish Academy of Sciences, Krakow, Poland

\section{Introduction}

The late Miocene fossiliferous localities of the Axios River valley, near Thessaloniki, Greece, span from the early Vallesian (MN 9) to the late Turolian (MN 13), and have yielded a significant amount of fossil mammals since their initial discovery at the beginning of the twentieth century (Arambourg and Piveteau 1929; Koufos 2006 and references therein). The abundance of fossil material and the geographic position of the Axios valley along the route between Anatolia and the Balkan Peninsula, renders this region crucial to our understanding of late Miocene vertebrate dispersals. Frustratingly, the main focus of 
palaeontological research has centered on mammals, which are by far the most abundant. Lizards and snakes, on the other hand, had never been described from the Axios Valley so far.

We here describe the first squamates, (i.e., lizards and snakes), from the late Miocene (MN 10) locality of Ravin de la Pluie, which is located in the Axios Valley and is primarily known for its hominoid primate Ouranopithecus macedoniensis (Koufos 2006). The specimens described herein are the first reptiles known from Ravin de la Pluie, with the exception of few testudinid turtles (Arambourg and Piveteau 1929; Garcia et al. 2011; Georgalis and Kear 2013). These new lizards and snakes are the only ones recorded from the late Vallesian MN 10 zone of southeastern Europe, and as such, provide significant biogeographical data. Among the material, there are appendicular remains that pertain to varanid lizards, and these elements are compared with all the few other limb fossils that have been attributed to this clade from the Neogene of Europe. The importance of the varanid vertebrae for taxonomic purposes is also addressed.

\section{Materials and methods}

All specimens described herein are permanently curated at the collections of LGPUT and accessioned under the "RPl" acronym. Part of this material was simply mentioned, but not described or figured, in a preliminary faunal list of de Bonis et al. (1992), where they reported the presence of "Boidae indet." and "Palaeonaja sp.". Our investigation of the material, however, concluded that no booid is present in this collection, and most probably this was a misidentification of the colubrid described below or some other specimen, which remained still unprepared at that time. The presence of an elapid snake in Ravin de la Pluie is here confirmed, though this taxon is described as Naja sp., considering that the usage of the genus name Palaeonaja is now considered obsolete (see below). Comparative material includes numerous skeletons of extant squamates housed in HNHM, MDHC, MNCN, MNHN, NHMW, and ZZSiD.

\section{Geological setting and palaeoecology}

The locality Ravin de la Pluie, (hereafter RPl) is situated near the village of Nea Messimvria in Axios Valley, about $25 \mathrm{~km}$ west of Thessaloniki city. It is located into the Nea Messimvria Formation and more exactly in the upper parts of the Formation, which is rather thick and consists mainly of sands, gravels, loose or hard conglomerates and red clay. Ravin de la Pluie is a well-known locality because of its rich mammal fauna and mainly the presence of the hominoid Ouranopithecus macedoniensis. Apart from $O$. macedoniensis, the RPl mammal fauna includes the erinaceid Palerinaceus sp., the sciurid Spermophilinus sp., the murid Progonomys cathalai, the hyaenids Adcrocuta eximia leptorhyncha, Hyaenictis sp., Protictitherium thessalonikensis, and Protictitherium aff. intermedium, the mustelid Eomellivora wimani, the felid Metailurus parvulus, the gomphotheriid Choerolophodon pentelici, the deinotheriid Deinotherium giganteum, the equids Hipparion macedonicum and Hipparion cf. sebastopolitanum, an indeterminate rhinocerotid, the giraffids Palaeogiraffa major, Palaeotragus cf. coelophrys, Palaeotragus cf. rouenii, and Bohlinia cf. attica, and the bovids Mesembriacerus melentisi, Palaeoryx sp., Prostrepsiceros vallesiensis, and Samotragus praecursor (Koufos 2006, 2012a, b). The study of the fauna suggests a late Vallesian, MN 10 age, with more exactly magnetostratigraphic correlations providing an estimated age of $\sim 9.3 \mathrm{Ma}$ (Koufos 2013).

Several studies, using various methods, have been carried out for the determination of the Vallesian palaeoenvironment of Axios Valley; the conditions were warm and dry, and the landscape was an open savannah-like with low vegetation (small trees, bushes, shrubs) and a thick herbaceous layer (e.g., de Bonis et al. 1992, 1999; Koufos 2006; Merceron et al. 2007; Rey et al. 2013). This is consistent with the palaeoecology of the herpetofauna of RPl. Varanids, large anguids, and elapids occupy a wide range of palaeoenvironments, ranging from savannah grasslands, deserts and forests (e.g., Pianka et al. 2004; Čerňanský et al. 2017a). However, the combination of the reptilian fauna of Ravin de la Pluie and the generally large size of its taxa, along with the associated mammalian fauna, lead us to consider a savannah grassland as the most plausible ecological setting of the locality.

\section{Systematic palaeontology}

\author{
Squamata OPPEL, 1811 \\ Anguimorpha FÜRBRINGER, 1900 \\ Anguidae GRAY, 1825 \\ Anguinae GRAY, 1825 \\ ?Anguinae indet.
}

Material. - One caudal vertebra (RPl 299) (Fig. 1).

Description. - RPl 299 is a well preserved caudal vertebra. The vertebra is procoelous and relatively large-sized, with a centrum length of $11 \mathrm{~mm}$. Both cotyle and condyle are dorsoventrally depressed, with the former being larger than the latter. In lateral view, the cotyle is orientated relatively anteroventrally. Two robust haemapophyses are 


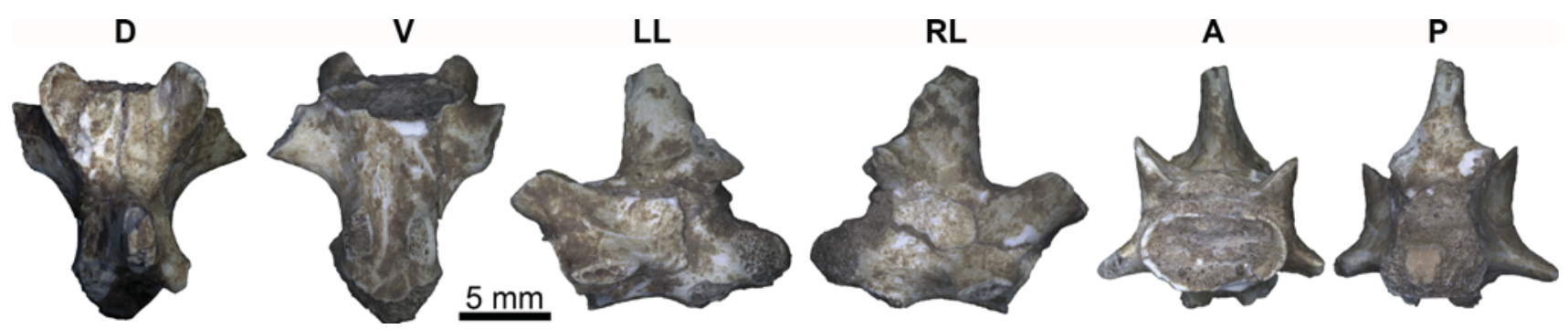

Fig. 1 ?Anguinae indet. from the late Miocene (MN 10) of Ravin de la Pluie. Caudal vertebra (RP1 299). $A$ anterior view, $D$ dorsal view, $L L$ left lateral view, $P$ posterior view, $R L$ right lateral view, $V$ ventral view

present and fused to the ventral surface of the centrum. Their posterior borders are relatively close to the condyle but are clearly separated from it. Only their bases are preserved. They are compressed mediolaterally but are not laminar. The neural canal is subtriangular in anterior view. The neural arch has its anterior end dorsally flattened but it becomes gradually more arched in its posterior portion. Striae are present on the neural arch. The neural spine is rather high in lateral view, confined only to the posterior portion of the neural arch, and becomes gradually thinner at its dorsal tip. The transverse processes are large and flattened, although both their edges are damaged. There is no visible autotomic fracture plane. Prezygapophyseal articular facets are broadened, flattened and tilted dorsally at $50^{\circ}$ in anterior view. Their main axis is directed anteriorly.

Remarks. - By certain aspects, caudal vertebrae of large anguids resemble strongly those of varanids (e.g., Estes 1983). Among the distinctive features of the two clades, the haemapophyses (= chevrons) of varanids are articulated on two pedicles, whereas those of anguids are fused to the centrum. More specifically, in Varanus, each pedicle ends as an articular facet that faces posteroventrally, but in RPI 299 , the remains that are close to the condyle cannot be considered to be such pedicles. They have no posteroventrally oriented facets, though their ends are apparently broken. As such, they are considered to be bases of broken fused-haemapophyses. Concerning the morphology of the neural spine, most, but not all, caudal vertebrae of anguines have tubular and posteriorly inclined neural spines. However, the two or three anteriormost caudal vertebrae of anguines (as also the sacral ones) have laterally compressed and vertical (or almost vertical) neural spines similar to those of varanids (personal observation by JCR and GLG on specimens of Pseudopus apodus and Ophisaurus harti in MNHN; see also a caudal vertebra of Pseudopus pannonicus illustrated in Fejérváry-Lángh (1923: plate III, Fig. 3), where the neural spine is not tubular but compressed laterally and almost vertical). On the other hand, we admit that the morphology and thickness of the haemapophyses, the orientation and thickness of the transverse processes, and the almost vertical angle of the neural spine of RPI 299, are features that are observable in the posterior caudal vertebrae of large-sized varanids. Additionally, a potential varanid attribution of RPl 299 would be further supported by the absolute size of the vertebra, along with what could be an indication of precondylar constriction (seen in ventral view), though the latter is most probably due to erosion and not a real feature of the specimen. Accordingly, the caudal vertebra RPI 299 is tentatively assigned to Anguidae, although we acknowledge the fact that it may in fact pertain to Varanidae, which also occur in this locality (see below). If RPl 299 belongs indeed to an anguid, then it should be assigned to Anguinae on the basis of the well forwarded haemapophyses fused to the centrum (MiklasTempfer 2003), taking also into consideration the total absence of the sole other known European anguid clade, Glyptosaurinae, after the late Eocene in the continent (Augé 2005; Rage 2013). Attribution of anguine caudal vertebrae to the species or genus level is not possible (e.g., Čerňanský et al. 2017a, b; Georgalis et al. 2017a). Nevertheless, and if the anguid identity of the specimen is correct, we here suggest possible affinities with Pseudopus pannonicus (Kormos, 1911), a widespread Mio-Pliocene taxon, characterized among others by its large size (Klembara and Rummel 2018). Such taxonomic allocation, however, is only based on the rather large size of RPI 299, taking also into consideration a geographic and stratigraphic rationale, and thus should only be considered as tentative.

Platynota DUMÉRIL AND BIBRON, 1839

Varanidae GRAY, 1827 (sensu ESTES ET AL., 1988) Varanus MERREM, 1820

Varanus sp.

Material. - Two presacral vertebrae (RPl 297-298) (Fig. 2); a humerus (RPl 295) (Fig. 3a, b, d); a tibia (RPl 296) (Fig. 3e, f).

\section{Description.}

Presacral vertebrae. - RPl 297 is a robust trunk vertebra, with a centrum length of $13 \mathrm{~mm}$, missing the right prezygapophysis, right synapophysis, and part of the neural 
a
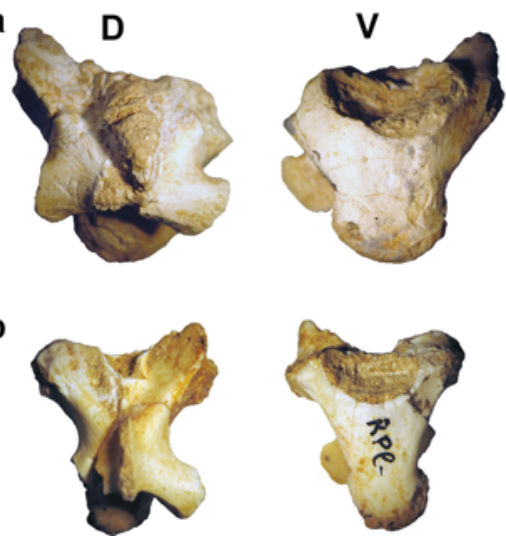

LL
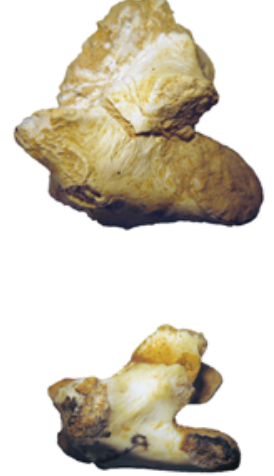

$\mathbf{R L}$
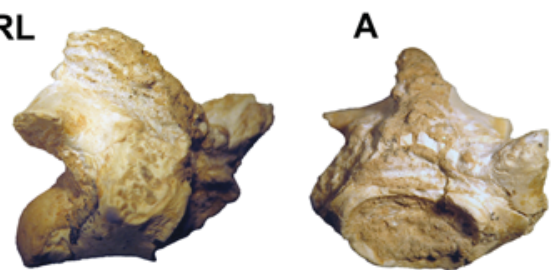

$5 \mathrm{~mm}$
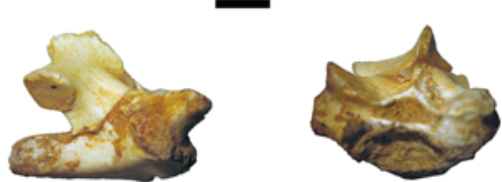

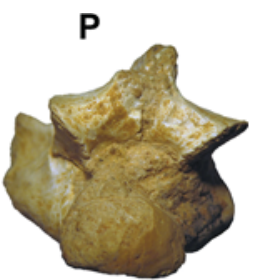

Fig. 2 Varanus sp. from the late Miocene (MN 10) of Ravin de la Pluie. a Presacral vertebra (RP1 297); b Presacral vertebra (RPl 298). A anterior view, $D$ dorsal view, $L L$ left lateral view, $P$ posterior view, $R L$ right lateral view, $V$ ventral view

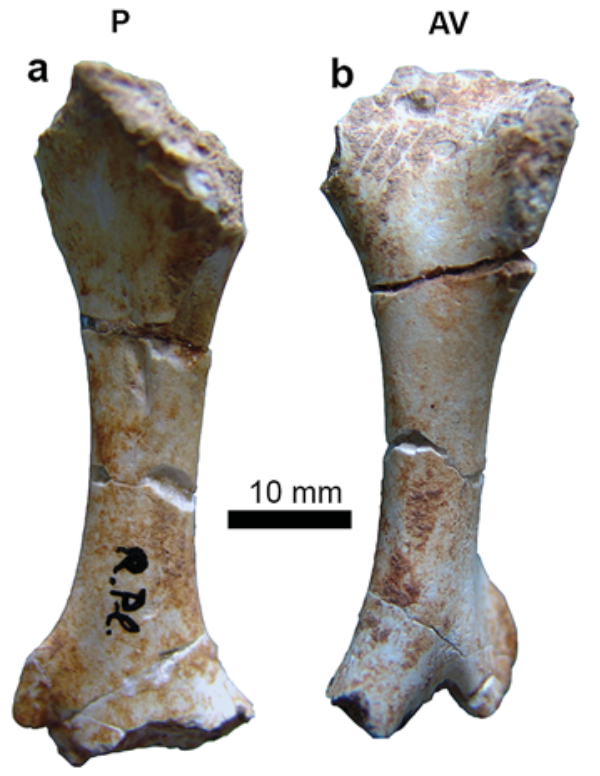

AV
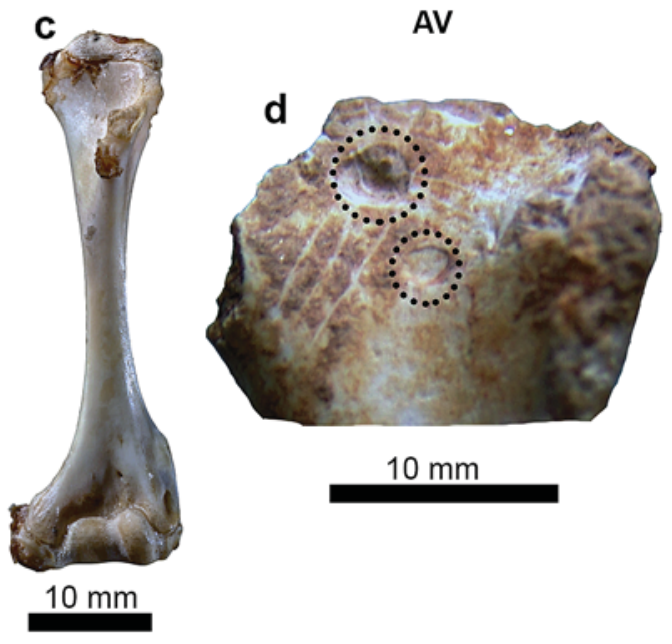

Fig. 3 Varanus sp. from the late Miocene (MN 10) of Ravin de la Pluie and extant Varanus griseus. a, b Left humerus (RPl 295) of Varanus sp. from RPl; $\mathbf{c}$ left humerus of an extant adult, small sized (total length about $60 \mathrm{~cm}$ ), Varanus griseus from northern Africa (MNHN uncatalogued); $\mathbf{d}$ magnification of the proximal part of the humerus (RPl 295) of Varanus sp. from RPl, with dotted circles indicating the two most prominent bite marks; $\mathbf{e}, \mathbf{f}$ right tibia (RPl

spine. RPl 298 is also a presacral vertebra, with a centrum length of $12 \mathrm{~mm}$, much less robust than the former specimen, but it is much better preserved, missing only the top portion of the neural spine, part of the left prezygapophysis, left synapophysis, and most of the left postzygapophysis. For the sake of convenience, as centrum length we here regard only the measurement between the tip of the condyle and the ventral margin of the cotyle (minimum centrum length of Bailon and Rage 1994). Both vertebrae are procoelous, and in ventral view, the centrum is triangular in shape. In lateral view the centrum is slightly convex ventrally, just prior to the level of the condyle in
D

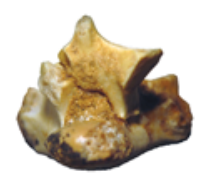

296) of Varanus sp. from RPl. Orientation of the bones follows Russell and Bauer (2008). Note the difference in the stoutness among the humeri of the extant and the Miocene Varanus and the difference in torsion between RPL1 295 and the humerus of V. griseus. The distal extremities show the same face, but the proximal ends are oriented differently. $A$ anterior view, $A V$ anteroventral view, $D$ dorsal view, $P$ posterior view, $V$ ventral view

RPl 297, but it is relatively straight ventrally in RPl 298. The ventral surface of the centrum in both vertebrae is generally smooth, but two rather small ventral foramina are present in RPl 297. A precondylar constriction is clearly present in both vertebrae. Both cotyle and condyle are dorsoventrally depressed, with the former being larger than the latter. The cotyle faces anteroventrally so that, in ventral view, the inner surface of the cotyle is largely visible. The condyle is strongly inclined posterodorsally in lateral view, and it is oval-shaped in posterior view, with a horizontal main axis. The ventral edge of the condyle is close to the posterior edge of the centrum so that only a 
little portion of the condyle is visible in ventral view. The prezygapophyseal facets are clearly dorsally tilted and they extend anteriorly well beyond the level of the cotyle. Judging from RPl 298, where they are much better preserved, the prezygapophyseal facets are large and ovalshaped. The anterior edge of the neural arch is low and the arch gradually increases in height posteriorly. A distinct, though not fully preserved, pars tectiformis is present in the anterior part of the neural arch. There seems to be a groove between the pars tectiformis and the margins of the prezygapophyses. The posterior edge of the neural arch is relatively well preserved in both vertebrae, with posterodorsal edges inclined quite steeply in posterior view, especially observable in RP1 297. No "pseudozygosphene" or "pseudozygantrum" is present in anterior and posterior views in any of the two vertebrae. The postzygapophyses are well preserved in RPl 297 (only the right one is complete in RP1 298) and they are enlarged and tilted dorsally at about $45^{\circ}$. The texture of the lateral and dorsal surfaces of the vertebrae shows distinct fibrous striae. The neural spine is broken and its height cannot be determined, although it is better preserved in RPl 298. It seems though that its base was developed along most of the posterior length of the neural arch. The neural canal is relatively rounded or rectangular-shaped posteriorly, whereas anteriorly it is dorsally arched and ventrally flattened. Synapophyses are not well preserved in both specimens. Only the left synapophysis of RPl 297 is present, but highly eroded (no diapophysis and parapophysis can be defined), but its extent denotes that it must have been relatively massive in life, whereas in RPl 298 the right synapophysis is also eroded but there are remnants of diapophysis and parapophysis.

Humerus. - RPl 295 is a left humerus whose extremities are severely damaged. More specifically, the proximal end lacks the humeral condyle and the lateral and medial tuberosities, whereas the condyles of the distal extremity are broken away. The bone is stoutly built. The proximal extremity was likely slightly wider than the distal end. The torsion of the bone appears to be moderate. The dorsal face of the diaphysis is flattened. On the anteroventral face, the proximal extremity forms a broad, shallow depression (bicipital fossa of Russell and Bauer 2008) that is limited laterally by the bases of the broken off deltopectoral and humeral crests. The distal extremity comprises the bases of the epicondyles, which limit the relatively small radioulnar fossa (fossette sus-trochléenne of Lécuru 1969). The entepicondyle is damaged, but its remaining base shows that it was larger than the ectepicondyle. A short ectepicondylar ridge extends proximally to the ectepicondyle. The presence of an ectepicondylar foramen is not certain. A notch in the broken distal extremity of the ectepicondylar ridge, visible in posterior aspect, may correspond to the proximal part of this foramen, but this cannot be confirmed. On the anteroventral face of the proximal extremity, groove-shaped cuts are present and could probably indicate bite marks from a predator or a scavenger.

Tibia. - RPI 296 represents a right tibia. It is stout and slightly sigmoid in dorsal aspect. Both extremities are eroded but are not markedly broken away. The proximal extremity expands more widely than the distal one. The diaphysis is somewhat compressed dorsoventrally so that it appears to be narrower in anterior or posterior views than in dorsal or ventral views. The proximal half of the diaphysis bears a well-developed ventral crest, which projects anteriorly. There is no other crest or process on this specimen.

Remarks. - The two presacral vertebrae RPl 297 and 298 can be attributed to Varanidae on the basis of: (1) the presence of a well demarcated anterior part (pars tectiformis) on the neural arch, (2) the morphology of the ventral surface of the centrum that is widened anteriorly and convex ventrally in cross section, and (3) the shape of the condyle that is strongly depressed, with its articular surface facing mainly dorsally (Rage and Bailon 2005). The two RPl vertebrae can be further assigned to Varanus on the basis of the prominent precondylar constriction and the presence of striae on the neural arch (Bailon and Rage 1994; Smith et al. 2008; Delfino et al. 2013). Such generic attribution is also strongly consistent with a biogeographic rationale, as Varanus is the sole recognized genus of varanids from the European Neogene and Quaternary (Georgalis et al. 2017b). It is worth noting that due to the anteroventral orientation of the cotyle in the vertebrae of Varanus [a feature also present in helodermatids (Augé 2005)], two different centrum lengths can be estimated, one minimum (length between the tip of the condyle and the ventral margin of the cotyle) and one maximum (between the tip of the condyle and the dorsal margin of the cotyle) (Bailon and Rage 1994; Delfino et al. 2013).

Appendicular elements of European fossil varanids have been only rarely documented and figured in the literature, with only few exceptions (e.g., de Fejérváry 1918; Sanz 1977; Venczel 2006). Their documentation is further hindered by the conservative nature of the morphology of the lizard limb elements, in addition to the scarcity of extant squamate skeletons in herpetological collections (Bell and Mead 2014). As such, the new limb elements from RPl add to the appendicular fossil record of varanids, though they are not significantly informative from a taxonomic point of view. The similar size and stoutness of the humerus and tibia suggest that they might belong to the same individual, which is consistent with their relative length (taking into account the poor condition of the extremities of both bones, the humerus was likely slightly longer than the tibia). On the other hand, the two bones are clearly more robust, less slender than those of extant Varanus of similar sizes, and 
even somewhat larger, which could even cast doubt on their referral to Varanus. However, the RPl fauna includes only two large-sized lizards, a potential large anguine and Varanus, with the former being limbless. In addition, various features are consistent with Varanus. On the humerus, the diaphysis is flattened, the proximal extremity was apparently slightly wider than the distal one, the bicipital fossa is shallow and broad, the entepicondyle is clearly larger than the ectepicondyle, and the ectepicondylar crest is well developed (Lécuru 1969; Russell and Bauer 2008). Moreover, the ventral crest of the tibia is strong. The distinctive scars on the humerus (Fig. 3c), one of which is deeper than the others, most probably originate from bite marks of a predator or a scavenger, and thus offer an insight into the palaeoecology of the area. Their size and shape is not consistent with bite marks from other varanids, so they do not probably originate from some kind of intraspecific fight. Instead, they more seem to correspond to the teeth of the hyaenid Protictitherium, which also occurs at the same locality. So far, the only similar record concerned predation or scavenging of varanid lizards on other taxa (e.g., Molnar 2004), but the opposite case with other fossil taxa preying or scavenging upon monitor lizards was up to now undocumented. As such, if our suggestion is correct, then this is the first recorded case of predation or scavenging upon fossil varanids.

Serpentes LINNAEUS, 1758

Alethinophidia NOPCSA, 1923

Colubridae OPPEL, 1811

"Colubrinae" OPPEL, 1811 (sensu SZYNDLAR, 1991a)

"Colubrinae" indet.

Material. - A series of incomplete vertebrae embedded in matrix (RPl 302) (Fig. 4).

Description. - RP1 302 is a series of few, probably articulated but rather eroded vertebrae. All vertebrae are rather small, with the largest one attaining a centrum length of only $4 \mathrm{~mm}$. The first vertebrae of the series bear a white sediment colour, whereas the rest bear a black one. Their centrum is slightly longer than wide. On the ventral side of the vertebrae, a haemal keel is present, it is broad and poorly defined laterally, but its posterior limit is clearly marked and pointed. There is no sign of a hypapophysis. All synapophyses are damaged. Only in the first vertebra, a prezygapophysis is preserved, visible only in ventral view. The condyle is rounded.

Remarks. - The centrum of the vertebrae in RPl 302 is reminiscent of both booids and colubrids. However, the small vertebral size and the marked posterior edge of the haemal keel make colubrid affinities as more plausible. Among colubrids, the presence or absence of a hypapophysis in the mid- and posterior trunk vertebrae has been considered as the most significant character in distinguishing "colubrine" from natricine snakes (Szyndlar 1991a, b, 2012). It is well recognized though that this traditional practice is more like a convenience rather than pragmatic taxonomy, as other European colubrids (sensu lato), now erected to family level, like psammophiids, also lack hypapophyses in their trunk vertebrae. Consequently, we follow the approach of Szyndlar (1991a, b, 2012) in using the term "Colubrinae" in quotation marks, denoting the presence of a non-natricine colubrid. Nevertheless, the RPI "colubrine" specimen is rather eroded and it is not possible to deduct a more accurate taxonomic attribution.

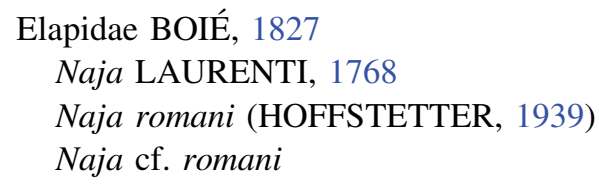

Material. - Two precloacal vertebrae (RPl 300-301) (Fig. 5a, b).

Description. - RPl 300 is a large and rather robust precloacal (probably mid-trunk or posterior trunk) vertebra with a centrum length of $10 \mathrm{~mm}$, missing its neural spine,
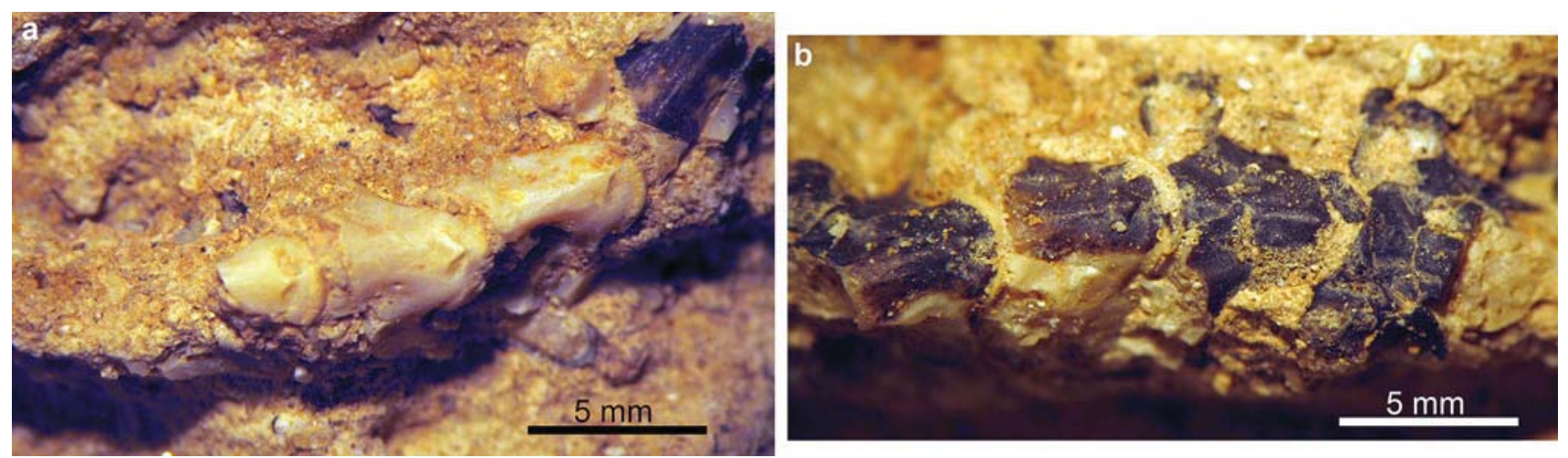

Fig. 4 "Colubrinae" indet. from the late Miocene (MN 10) of Ravin de la Pluie. a Portion of the matrix with articulated vertebrae (RP1 302). b Different portion of the same matrix with articulated vertebrae (RPl 302) 

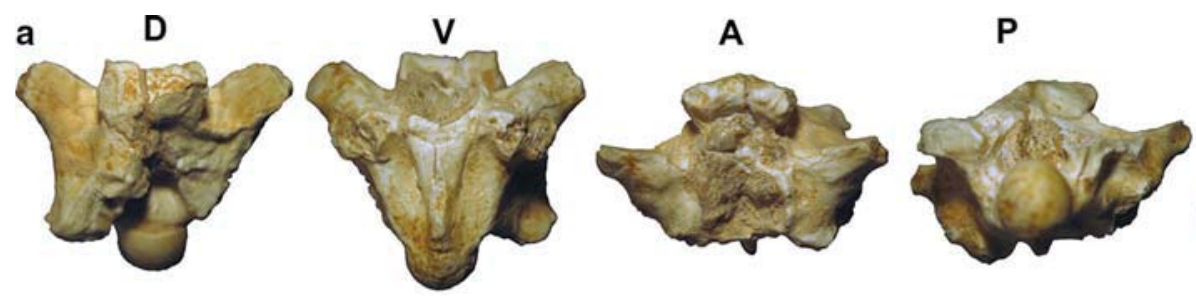

RL
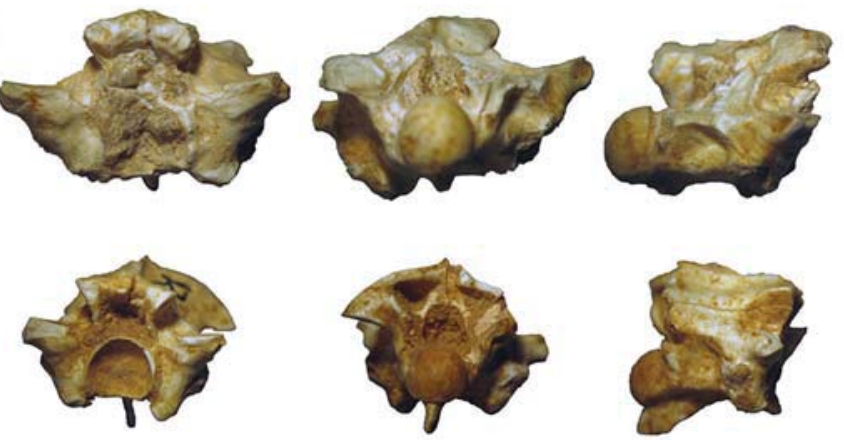

b
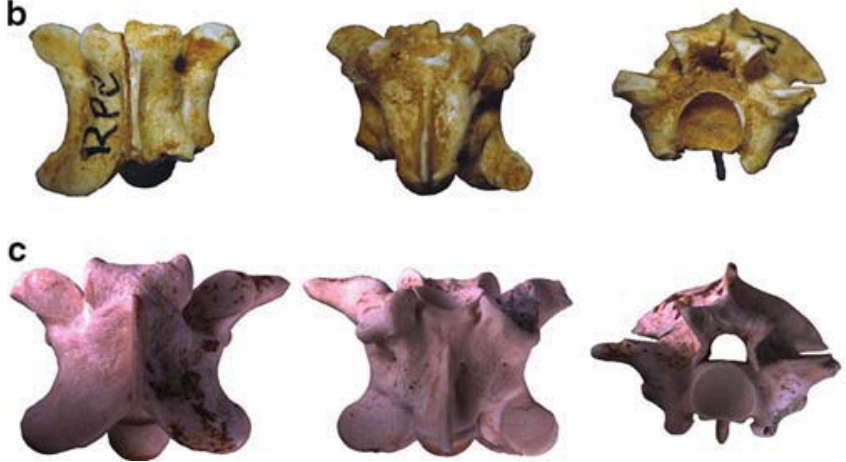

Fig. 5 Naja cf. romani from the late Miocene (MN 10) of Ravin de la Pluie and Naja romani from the late Miocene (MN 11) of Kohfidisch, Austria. a Precloacal vertebra (RP1 300) of Naja cf. romani from RPl; b Precloacal vertebra (RPl 301) of Naja cf. romani from RPl;

right postzygapophysis, and parts of the neural arch, synapophyses, and hypapophysis. RPl 301 is a smaller precloacal vertebra, with a centrum length of $8 \mathrm{~mm}$, missing most of its neural spine and the right postzygapophysis. The centrum is triangular in shape and rather broad, especially in the case of RPl 300. The zygosphene is slightly convex in anterior view, whereas in dorsal view, it is slightly crenate in RPl 301 and concave in RPl 300. The neural arch is vaulted and wide in posterior view in RPl 301, but is eroded in RPl 300. The height of the neural spine cannot be evaluated in any of the specimens, as this element is damaged in RPl 300 and only remnants of its base are still present in RP1 301. Nevertheless, it seems that the neural spine extended much of the surface of the neural arch, at least in the case of RPl 301. In lateral view, the interzygapophyseal ridges are prominent. Lateral foramina are present in both vertebrae and are situated in deep depressions. In lateral view, the subcentral ridges are relatively straight over most portion of the vertebra, but become arched dorsally at the level above the hypapophysis. In ventral view, the subcentral ridges are prominent and the subcentral grooves are deep. The keel that prolongs the hypapophysis anteriorly is rather thick in RPl 300 and thin in RPl 301. The hypapohysis is complete in RPl 301 but only its base is preserved in RPl 300. In RPl 301, it is laterally compressed and strongly inclined posteriorly, with its posterior tip being obtuse and situated below the level of the condyle. Prezygapophyses are robust and thick in RPl 300 but not so prominent in RPl 301. In both cases, however, they are produced laterally and only rather slightly
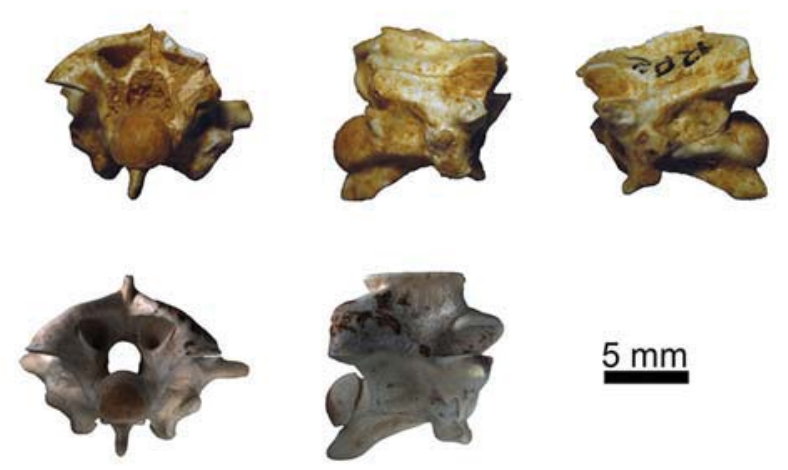

$5 \mathrm{~mm}$

c Precloacal vertebra (NHMW 2004z0038.0009) of Naja romani from Kohfidisch (courtesy of NHMW). $A$ anterior view, $D$ dorsal view, $L L$ left lateral view, $P$ posterior view, $R L$ right lateral view, $V$ ventral view

inclined dorsally. Prezygapophyseal articular facets are rather wide and oval-shaped. Prezygapophyseal processes are mostly eroded in both vertebrae and, as such, their extent cannot be evaluated. Synapophyses are distinctly divided into diapophyses and parapophyses. These are relatively eroded in RPl 300, but judging from RPl 301 where they are much better preserved, diapophyses are robust and hemisphaerical, parapophyses are wide and relatively flat, whereas parapophyseal processes are directed anteroventrally. Cotyle is rounded, rather large, and relatively deep, especially in the case of RPl 301. Paracotylar foramina are small, situated at the inner margins of deep depressions next to the cotyle. Condyle is rather robust and almost hemisphaerical.

Remarks. - The presence of hypapophyses in the midtrunk vertebrae is an important feature shared by relatively closely related snake clades, such as natricines, elapids, and viperids (Szyndlar 1991a, b), but also distant clades such as acrochordids and bolyeriids. The latter two clades, though, have never been recorded from Europe. RPl 300 and 301 have a relatively large size for natricine snakes. Apart from size, the two vertebrae can be precluded from association with natricines, on the basis on general shape and the shape and inclination of hypapophysis and parapophyses (Szyndlar 1991a, b). Furthermore, the sizes of the cotyle and the condyle do not fit those of viperids, as in the latter clade, the cotyle and condyle are larger (Szyndlar and Rage 1999, 2002; Georgalis et al. 2016a). Moreover, in viperids, the neural arch, in posterior view, is more depressed, and in large vipers (i.e., the "Oriental vipers complex") it is even 
flattened (Szyndlar and Rage 1999, 2002; Georgalis et al. 2016a). In addition, the morphology of the ventral face of the centrum and the laterally compressed hypapophysis are characteristic of elapids, and they are clearly consistent with the "Naja group" (Szyndlar and Zerova 1990; Szyndlar 1991b). Unfortunately the prezygapophyseal accessory processes, which could be informative for a more precise taxonomic allocation of the specimens, are poorly preserved in both RPI 300 and 301. The morphology of the zygosphene (with three lobes in the smaller vertebra and the median lobe disappearing in the larger one) is consistent with that of Naja romani, a widespread species from the Miocene of Europe (Fig. 5c). Accordingly, the new Axios cobra is provisionally referred to this taxon. Differences in the size and shape of RPl 300 and 301 are attributed to ontogenetic or intracolumnar variation.

\section{Discussion}

\subsection{Palaeobiogeography}

The new fossil lizards and snakes from RPl described herein fill an important gap into our knowledge of Eastern Mediterranean Miocene squamate faunas, as this material is the first recorded from the MN 10 zone from southeastern Europe and only the third such record from the whole continent. Indeed, in terms of herpetofaunas, MN 10 is a poorly recorded zone, with only two other European squamate-bearing localities pertaining to that age. These two other localities are Vösendorf, Austria, which has yielded a small-sized anguine, a lacertid, and a "colubrine" (the latter originally erroneously identified as an anilioid) (Papp et al. 1953), and Soblay, France, which has yielded an erycid snake (Demarcq et al. 1983). Even more frustratingly, this latter record from France was simply mentioned but never described or figured, and it cannot now be located. Within southeastern Europe, the new squamate finds (varanids, anguids, "colubrines" and elapids) from RPl rank chronologically intermediate between those from Plakias (Crete Island) (MN 9) (amphisbaenians and natricines; Georgalis et al. 2016b) and those from Pikermi (varanids; Gaudry 1862, 1862-1867; Weithofer 1888) and Mytilinii (Samos Island) (varanids; Conrad et al. 2012) (both MN 12). Considering the different faunal composition between Plakias, Ravin de la Pluie, Pikermi, and Samos, this does not necessarily indicate real absence of certain clades from these localities, but most probably reflects different ecological settings or preservational and collection bias.

The common presence of varanids in Ravin de la Pluie, Pikermi, and Samos, clearly indicates that monitor lizards were geographically widespread in the Greek area at least between the MN 10 to MN 12. Whether this geographic distribution was also reflected by high taxonomic richness of varanids, though, as it is currently indicated by different species known from skull elements in Pikermi (Varanus marathonensis Weithofer, 1888) and Samos (Varanus amnhophilis Conrad et al., 2012), cannot be evaluated with certainty, as there is no varanid cranial material from RPl, and, moreover, the type material of $V$. marathonensis needs to be reassessed under modern taxonomic and phylogenetic concepts. The presence of several sympatric varanid taxa in various modern herpetofaunas (Pianka et al. 2004) offers, at least, ecological support for envisaging the scenario of more than one late Miocene varanids inhabiting southeastern Europe. In any case, varanids have persisted in the Greek area for a much longer period, until at least the Middle Pleistocene, judging from recently described cranial remains from Tourkobounia 5, near Athens, which also represent the youngest occurrence of monitor lizards from Europe (Georgalis et al. 2017b).

Anguids have so far been described from the Miocene of Greece in the localities of Ano Metochi (MN 13) (Georgalis et al. 2017a) and Maramena (MN 13/14) (Richter 1995), both situated in the Serres Basin in northern Greece. However, in both latter localities, anguids are represented by relatively small-sized forms, probably allied with Ophisaurus. As such, if the caudal vertebra from RPl belongs indeed to anguids, then it denotes the presence of a rather large-sized animal, probably allied with the largest known anguine lizard, Pseudopus pannonicus. Late Miocene occurrences of this widespread taxon or similar giant forms are known from Austria (Bachmayer and Młynarski 1977), Hungary (Kormos 1911; Fejérváry-Lángh 1923; Klembara 1981; Venczel 2006), Italy (Kotsakis 1989), Ukraine (Fejérváry-Lángh 1923), and probably Slovakia (Čerňanský 2011). Giant anguids with supposed affinities with $P$. pannonicus continued to inhabit Europe during the Pliocene (Fejérváry-Lángh 1923; Młynarski 1956, 1964; Bachmayer and Młynarski 1977; Młynarski et al. 1984; Delfino 2002; Blain and Bailon 2006; Čerňanský et al. 2017a), persisting even until the Pleistocene (Bolkay 1913). Whether all these Miocene, Pliocene, and Pleistocene specimens belong indeed to a single species or they are different taxa of a species complex of giant anguids, remains to be tested through a comprehensive revision of all this material. As such, if our identification is correct, this new specimen demonstrates for the first time the presence of "giant" anguids in Greece. It is worth noting that the largest extant lizard from Europe, Pseudopus apodus, shares strong affinities with its Miocene giant relative, $P$. pannonicus, and is still a significant component of the living herpetofauna of the RPl area.

Two fossil snakes have been identified in the collection of squamates from Ravin de la Pluie. Of these, the 
"colubrine" is not adequately preserved and its exact taxonomic affinities cannot be further elucidated. As such, it is of no relevant significance for biogeographic considerations, but nevertheless adds to the previously poor Miocene record of Greek "colubrines", which to date comprises only material from localities within the Serres Basin (Szyndlar 1991a, 1995; Georgalis et al. 2017a). Among extant non-natricine colubrids, both colubrines (sensu stricto) and psammophiids [i.e., Malpolon insignitus (Geoffroy-Saint-Hilaire, 1827)] inhabit today the area of the Axios valley. On the other hand, the new fossil cobra (i.e., Elapidae) from RPl represents the earliest occurrence of elapids in Greece, which were otherwise exclusively known from the late Miocene of Maramena (Szyndlar 1991b, 1995) and the late Pliocene of Tourkobounia 1, near Athens (Szyndlar and Zerova 1990). Additional material from the Middle Pleistocene of Chios Island that was described by Schneider (1975) as a cobra, was subsequently suggested to belong to another snake lineage (Szyndlar 1991b). We agree with this view herein, and judging from the available figure of Schneider (1975), we consider this to be most probably a natricine snake. Cobras seem to be rather widespread in the European Neogene (Szyndlar and Rage 1990). Traditionally considered to represent an endemic, distinct genus (Palaeonaja) (Hoffstetter 1939; Rage and Sen 1976; Alberdi et al. 1981; Rage 1984), it was subsequently demonstrated that it in fact has strong affinities with the Asiatic stock of the extant Naja (Szyndlar and Rage 1990), a view that was subsequently followed by most authors (e.g., Szyndlar and Zerova 1990; Szyndlar and Schleich 1993; Szyndlar 1991b, 2005), with the notable exception of Wallach et al. (2014) who assigned all European fossil taxa to the African Afronaja, without, however, providing justification for their new taxonomic allocation. We herein follow the prevailing view that the Neogene cobras from Europe are all assigned to Naja. Apart from Greece, other known late Miocene occurrences of Naja include Austria (Bachmayer and Szyndlar 1985; Szyndlar and Zerova 1990), Hungary (Szyndlar 2005), Spain (Alberdi et al. 1981; Szyndlar 1985), and Ukraine (Szyndlar and Zerova 1990). Most likely, the Axios valley cobra could be conspecific with the widespread European taxon Naja romani, as the two forms share resemblance in terms of general shape and size (Fig. 5). Due to the incomplete nature of both RPl vertebrae, however, we treat this referral to the specific level as tentative. In any case, the new RPl cobra adds to the known stratigraphic and geographic distribution of these snakes into the Neogene of Europe.

\subsection{The taxonomic problem of varanid vertebrae}

The vertebrae of monitor lizards (Varanidae) are characterized by certain features that render feasible their taxonomic identification, even when dealing with isolated remains. As such, vertebrae represent the most abundant remains in the varanid fossil record (Estes 1983; Molnar 2004; Georgalis et al. 2017b). It is even characteristic that the first confirmed fossil varanid find from Europe was a large trunk vertebra (MNHN.F.PIK3715) from the late Miocene of Pikermi, originally described by Gaudry (1862, 1862-1867) as a "Reptile du groupe des Varans", that was subsequently referred to Varanus marathonensis by Weithofer (1888).

Whereas certain features of varanid vertebrae render them identifiable at the family or also at the genus level, differences among the most distinctive characters, such as the degree of the precondylar constriction and the angle of the anteroventral orientation of the cotyle, have been traditionally used in fossil squamate literature as taxonomically important features for monitor lizards, even as diagnostic for specific distinction (e.g., Roger 1898; Nopcsa 1908; Hoffstetter 1969; Lungu et al. 1983; Zerova and Chkhikvadze 1986). As a consequence, the following varanid species have been established exclusively on the basis of vertebrae from the European Cenozoic: Saniwa orsmaelensis Dollo, 1923, from the early Eocene (MP 7) of Belgium, Iberovaranus catalaunicus Hoffstetter, 1969, from the early Miocene (MN 4) of Spain, Varanus hofmanni Roger, 1898, from the middle-late Miocene (MN 6MN 9) of Germany, Varanus lungui Zerova and Chkhikvadze, 1986, from the middle Miocene (MN 7/8) of Moldova, Varanus tyrasiensis Zerova and Chkhikvadze in Lungu et al. (1983), also from the middle Miocene (MN 7/8) of Moldova, Varanus atticus Nopcsa, 1908, from the late Miocene (MN 12) of Greece, and Varanus semjonovi Zerova in Zerova and Chkhikvadze (1986), from the late Miocene (MN 12) of Ukraine. To these, we add also Varanus deserticolus Bolkay, 1913, from the late Pliocene (MN 16) of Hungary, which is in fact a chimaera, typified by a varanid dentary and an anguid vertebra (see Georgalis et al. $2017 \mathrm{~b}$ for further discussion), so it is not considered as exclusively established on vertebral material.

However, it has since been shown that the above mentioned purported diagnostic features (degree of the precondylar constriction and the angle of the anteroventral orientation of the cotyle) are highly variable among varanid vertebrae and they should only be considered with cautiousness upon dealing with taxonomic identifications (Smith et al. 2008; Holmes et al. 2010; Delfino et al. 2013). As such, the validity of most of these names is problematic or at least tentative. Iberovaranus catalaunicus has recently 
been shown to fall within the vertebral variability of Varanus and the name has been suggested to be a nomen dubium (Delfino et al. 2013). Varanus atticus is typified by the large vertebra from Pikermi that was originally described by Gaudry (1862, 1862-1867), and is now generally accepted as a synonym of $V$. marathonensis, which was established by Weithofer (1888) also from Pikermi, but on the basis of cranial material (e.g., de Fejérváry 1918; Rage and Sen 1976; Estes 1983; Molnar 2004). Varanus lungui and $V$. tyrasiensis are coeval and rather approximate geographically, whereas the Ukrainian $V$. semjonovi is younger than the two aforementioned Moldavian taxa but originates practically from the same region. Varanus hofmanni is generally treated as a valid taxon, with several other occurrences being provisionally referred to this species from the Miocene of France (Hoffstetter 1969), Hungary (Venczel 2006), and Spain (Hoffstetter 1969); as it is an important, historical taxon, its status needs to be reassessed. The status of Saniwa orsmaelensis is more clear: this Paleogene species is generally treated as valid (e.g., Hecht and Hoffstetter 1962; Augé 1990, 2005; Smith et al. 2008). Indeed, the vertebrae of Saniwa (currently the sole valid genus of European Paleogene varanids; Augé 2005) seem to be distinct from those of Varanus by, among others, the presence of a pseudozygosphene and a straight posterior border of the neural arch between the postzygapophyses (this line is V-shaped in Varanus) (Estes 1983; Rage and Augé 2003; Malakhov 2005; Smith et al. 2008).

The two RPl varanid vertebrae differ between them in terms of size, shape, length and extent of pre- and postzygapophyses, and slightly in their degree of precondylar constriction. Nevertheless, this does not imply that they belong to different varanid taxa, but rather that these differences most probably result from ontogenetic or intracolumnar variation (i.e., pertaining to different portions of the trunk region). Interestingly, both RPl vertebrae are much smaller than the stratigraphically younger one belonging to the Varanus originally described by Gaudry (1862, 1862-1867) from the late Miocene (MN 12) of Pikermi, that is generally referred to $V$. marathonensis. They further differ from the Pikermi specimen in terms of general shape, degree of precondylar constriction, angle of anteroventral orientation of the cotyle, extent and inclination of prezygapophyses, depression of cotyle and condyle, and size and shape of neural canal. Whether, however, the RPl varanid represents a distinct, smaller and potentially ancestral species to $V$. marathonensis, remains to be elucidated with the study of intraspecific variation among extant varanids and the potential recognition of phylogenetically important characters in these skeletal elements.

\subsection{Limb morphology of the European Neogene Varanus}

The limb bones (a left humerus and a right tibia) from the locality of RPl, which are referred to Varanus, are clearly more stoutly built than those of similarly-sized extant species of the same genus. The same observation concerns all other so far published limb elements (i.e., only four) from the Neogene of Europe that have been allocated to Varanus. These bones consisted so far solely of an ulna, a humerus, a femur, and a phalanx (de Fejérváry 1918; Sanz 1977; Venczel 2006). The ulna and femur were recovered from the latest Miocene (MN 13) of Polgárdi, Hungary, and were referred to as Varanus cf. hofmanni by Venczel (2006). The humerus, was identified as Varanus sp. and originates from the late Pliocene (MN 15) of Layna, Spain (Sanz 1977). The phalanx originates from the early Pliocene (MN 15) of Csarnóta, Hungary, that was referred by de Fejérváry (1918) to Varanus marathonensis. Judging from the new Greek material and the published figures of all the above mentioned appendicular remains from Spain and Hungary, it seems that all known limb elements of Varanus from the Neogene of Europe are much thicker and stouter than those of the living species (ratio of length/ thickness in Miocene forms is lower than in recent forms). This suggests that monitor lizards (i.e., Varanus) were represented during the Neogene of Europe by species with relatively short and stocky limbs. Judging from the wide stratigraphic and geographic distribution of short-limbed varanids in the Neogene of Europe, we tentatively suggest that this character was also apparent in all coeval forms from the continent. As such, it would not be surprising that Varanus marathonensis from Pikermi and its allied coeval forms from the Neogene of Europe, that are currently not known from any appendicular elements, could have also possessed this distinctive short and robust limb morphology that is apparent at least in the RPl, Polgárdi, and Layna varanids. Obviously, the small number of available specimens does not permit any definite conclusions. The recovery of more fossil limb bones of varanids and a more thorough investigation of the skeletal anatomy of the extant taxa is highly recommended.

\section{Conclusions}

We here describe new finds of lizards and snakes from the late Miocene of Ravin de la Pluie, a locality mostly known for its hominoid Ouranopithecus macedoniensis. The new finds represent the first record of fossil squamates from the Axios valley. The fauna is relatively not diverse, with a general trend towards large-sized taxa, though this is most 
probably an artifact of taphonomy and collection bias. Lizards include the varanid Varanus sp. and a probable large anguid. Snakes include the elapid Naja cf. romani and a small-sized "colubrine". The new squamates from RPl fill a gap in the biogeography and stratigraphy of these reptiles, as they are the first records of lizards and snakes from the late Miocene MN 10 biozone of southeastern Europe, and they complement the knowledge provided by the rare coeval records from the whole continent. The RPl finds further expand the known distribution records of varanids and elapids from southeastern Europe. The potential taxonomic credibility of varanid vertebrae is discussed, with implications about the validity of certain European monitor lizard taxa. The new varanid limb bones from RPl rank among the few such elements in the European record and indicate the presence of robust legs for the European Neogene monitor lizards. The identification of distinctive scars on the RPl varanid humerus corresponds probably to bite marks of a mammalian predator or a scavenger, and offers an insight into the palaeoecology of the locality.

Acknowledgements We thank Massimo Delfino (University of Torino) and Walter Joyce (University of Fribourg) for useful comments that enhanced the quality of the manuscript. Study of comparative material of extant squamates was funded by SYNTHESYS ES-TAF5910 (MNCN), SYNTHESYS AT-TAF-5911 (NHMW), and SYNTHESYS HU-TAF-6145 (HNHM) Grants to GLG, and the curators of these institutions, respectively, Marta Calvo-Revuelta, Heinz Grillitsch, and Judit Vörös are acknowledged here. We are also grateful to Salvador Bailon (MNHN) and Zbigniew Szyndlar (ZZSiD) for access to comparative specimens under their care to GLG and JCR, and Ursula Göhlich (NHMW) for allowing us to use the photographs of the Austrian Naja romani. We also thank Lilian Cazes (MNHN) for taking a photograph of the extant Varanus griseus humerus. We additionally thank the Editor Wilfried Winkler, and the reviewers Andrej Čerňanský and an anonymous one for their help during Editorial and Reviewing process. GLG acknowledges travel support from the University of Torino.

\section{References}

Alberdi, M. T., Morales, J., Moya, S., \& Sanchiz, B. (1981). Macrovertebrados (Reptilia y Mammalia) del yacimiento finimioceno de Librilla (Murcia). Estudios Geológicos, 37, 307-312.

Arambourg, C., \& Piveteau, J. (1929). Les Vertébrés du Pontien de Salonique. Annales de Paléontologie, 18, 59-138.

Augé, M. (1990). La faune de lézards et d'Amphisbènes (Reptilia, Squamata) du gisement de Dormaal (Belgique, Eocène inférieur). Bulletin de l'Institut Royal des Sciences Naturelles de Belgique, Sciences de la Terre, 60, 161-173.

Augé, M. (2005). Evolution des lézards du Paléogène en Europe. Mémoires du Muséum national d'Histoire naturelle, Paris, 192, 1-369.

Bachmayer, F., \& Młynarski, M. (1977). Bemerkungen über die fossilen Ophisaurus-Reste (Reptilia, Anguinae) von Österreich und Polen. Sitzungsberichte der Österreichischen Akademie der
Wissenschaften, Mathematischnaturwissenschaftliche KIasse Abteilung, 1(186), 285-299.

Bachmayer, F., \& Szyndlar, Z. (1985). Ophidians (Reptilia: Serpentes) from the Kohfidisch fissures of Burgenland, Austria. Annalen des Naturhistorischen Museums Wien, A, 87, 79-100.

Bailon, S., \& Rage, J.-C. (1994). Squamates Néogènes et Pléistocènes du Rift occidental, Ouganda. In B. Senut \& M. Pickford (Eds.), Geology and palaeobiology of the Albertine Rift Valley, UgandaZaire. Vol. 2: Palaeobiology (Vol. 29, pp. 129-135). Orléans: CIFEG Occasional Publications.

Bell, C. J., \& Mead, J. I. (2014). Not enough skeletons in the closet: Collections-based anatomical research in an age of conservation conscience. Anatomical Record, 297, 344-348.

Blain, S., \& Bailon, H.-A. (2006). Catalogue of Spanish PlioPleistocene amphibians and squamate reptiles from the Museu de Geologia de Barcelona. Trabajos del Museo Geologico Barcelona, 14, 61-80.

Boié, F. (1827). Bemerkungen über Merrem's Versuch eines Systems der Amphibien, 1-ste Lieferung: Ophidier (Vol. 20, pp. 508-566). Leipzig: Isis von Oken.

Bolkay, J. (1913). Additions to the fossil herpetology of Hungary from the Pannonian and Praeglacial periode. Mittheilungen aus dem Jahrbuche der königlichen Ungarischen geologischen Reichsanstalt, 21, 217-230.

Čerňanský, A. (2011). New finds of the Neogene lizard and snake fauna (Squamata: Lacertilia; Serpentes) from the Slovak Republic. Biologia, 66, 899-911.

Čerňanský, A., Szyndlar, Z., \& Mörs, T. (2017a). Fossil squamate faunas from the Neogene of Hambach (northwestern Germany). Palaeobiodiversity and Palaeoenvironments, 97, 329-354.

Čerňanský, A., Vasilyan, D., Georgalis, G. L., Joniak, P., Mayda, S., \& Klembara, J. (2017b). First record of fossil anguines (Squamata; Anguidae) from the Oligocene and Miocene of Turkey. Swiss Journal of Geosciences, 110, 741-751.

Conrad, J. L., Balcarcel, A. M., \& Mehling, C. M. (2012). Earliest example of a giant monitor lizard (Varanus, Varanidae, Squamata). PLoS ONE, 7, e41767.

de Bonis, L., Bouvrain, G., Geraads, D., \& Koufos, G. (1992). Diversity and paleoecology of Greek late Miocene mammalian faunas. Palaeogeography, Palaeoclimatology, Palaeoecology, 91, 99-121.

de Bonis, L., Bouvrain, G., \& Koufos, G. D. (1999). Palaeoenvironments of the hominoid primate Ouranopithecus in the late Miocene deposits of Macedonia, Greece. In J. Agusti, L. Rook, \& P. Andrews (Eds.), Hominoid evolution and climatic change in Europe, vol. I. The evolution of the Neogene terrestrial ecosystems in Europe (pp. 205-237). London: Cambridge University Press.

de Fejérváry, G. J. (1918). Contributions to a monography on fossil Varanidae and on Megalanidae. Annales Historico-Naturales Musei Nationalis Hungarici, 16, 341-467.

Delfino, M. (2002). Erpetofaune italiane del Neogene e del Quaternario. $\mathrm{PhD}$ dissertation, University of Modena and Reggio Emilia, Modena and Reggio Emilia, Italy.

Delfino, M., Rage, J.-C., Bolet, A., \& Alba, D. M. (2013). Early Miocene dispersal of the lizard Varanus into Europe: Reassessment of vertebral material from Spain. Acta Palaeontologica Polonica, 58, 731-735.

Demarcq, G., Ballesio, R., Rage, J.-C., Guérin, C., Mein, P., \& Méon, H. (1983). Données paléoclimatiques du Néogène de la Vallée du Rhône (France). Palaeogeography, Palaeoclimatology, Palaeoecology, 42, 247-272.

Dollo, L. (1923). Saniwa orsmaelensis, varanidé nouveau du Landénien supérieur d'Orsmael (Brabant). Bulletin de la Société Belge de Géologie, de Paléontologie et d'Hydrologie, 33, 76-82. 
Duméril, A. M. C., \& Bibron, G. (1839). Erpétologie générale ou histoire naturelle complète des reptiles. Paris: Roret.

Estes, R. (1983). Sauria terrestria, Amphisbaenia. In P. Wellnhofer (Ed.), Encyclopedia of paleoherpetology, part 10a. Stuttgart: Gustav Fischer Verlag.

Estes, R., de Queiroz, K., \& Gauthier, J. A. (1988). Phylogenetic relationships within Squamata. In R. Estes \& G. K. Pregill (Eds.), Phylogenetic relationships of the lizard families: Essays commemorating C.L. Camp (pp. 119-281). Stanford: Stanford University Press.

Fejérváry-Lángh, A. M. (1923). Beiträge zu einer Monographie der fossilen Ophisaurier. Palaeontologia Hungarica, 1, 123-220.

Fürbringer, M. (1900). Zur vergleichenden anatomie des Brustschulterapparates und der Schultermuskeln. Jenaische Zeitschrift, 34, 215-718.

Garcia, G., Lapparent de Broin, F. de, Bonis, L. de, Koufos, G. D., Valentin, X., Kostopoulos, D., \& Merceron, G. (2011). A new terrestrial Testudinidae from the Late Miocene hominoid locality "Ravin de la Pluie" (Axios Valley, Macedonia, Greece). In A. Van der Geer \& A. Athanassiou, A. (Eds.), 9th Annual Meeting of the European Association of Vertebrate Palaeontologists, Program and Abstracts (pp. 26-27). Heraklion: Natural History Museum of Crete.

Gaudry, A. (1862). Note sur les débris d'Oiseaux et de Reptiles trouvés à Pikermi, Grèce, suivie de quelques remarques de paléontologie générale. Bulletin de la Société Géologique de France, 19, 629-640.

Gaudry, A. (1862-1867). Animaux fossiles et géologie de l'Attique. Paris: Savy.

Geoffroy-Saint-Hilaire, I. (1827). Description des reptiles qui se trouvent en Égypte. In M. J. C. L. de Savigny (Ed.), Description de l'Égypte, ou recueil des observations et des recherches qui ont été faites en Égypte pendant l'expédition de l'armée Française. Histoire naturelle. Tome premier. Partie première (pp. 121-160). Paris: Imprimerie Impériale.

Georgalis, G. L., \& Kear, B. P. (2013). The fossil turtles of Greece: An overview of taxonomy and distribution. Geobios, 46, 299-311.

Georgalis, G. L., Szyndlar, Z., Kear, B. P., \& Delfino, M. (2016a), New material of Laophis crotaloides, an enigmatic giant snake from Greece, with an overview of the largest fossil European vipers. Swiss Journal of Geosciences, 109, 103-116.

Georgalis, G. L., Villa, A., \& Delfino, M. (2017a). Fossil lizards and snakes from Ano Metochi - a diverse squamate fauna from the latest Miocene of northern Greece. Historical Biology, 29, $730-742$.

Georgalis, G. L., Villa, A., \& Delfino, M. (2017b). The last European varanid: Demise and extinction of monitor lizards (Squamata, Varanidae) from Europe. Journal of Vertebrate Paleontology, 37, e1301946.

Georgalis, G. L., Villa, A., Vlachos, E., \& Delfino, M. (2016b). Fossil amphibians and reptiles from Plakias, Crete: A glimpse into the earliest late Miocene herpetofaunas of southeastern Europe. Geobios, 49, 433-444.

Gray, J. E. (1825). A synopsis of the genera of Reptiles and Amphibia, with a description of some new species. Annals of Philosophy, Series, 2(10), 193-217.

Gray, J. E. (1827). A synopsis of the genera of saurian reptiles, in which some new genera are indicated and others reviewed by actual examination. The Philosophical Magazine, or Annals of Chemistry, Mathematics, Astronomy, Natural History, and General Science, 2, 54-58.

Hecht, M., \& Hoffstetter, R. (1962). Note préliminaire sur les amphibiens et les squamates du Landénien supérieur et du Tongrien de Belgique. Bulletin de l'Institut royal des Sciences naturelles de Belgique, Sciences de la Terre, 38, 1-30.
Hoffstetter, R. (1939). Contribution à l'étude des Elapidae actuels et fossiles et de l'ostéologie des Ophidiens. Archives du Muséum d'Histoire Naturelle de Lyon, 15, 1-78.

Hoffstetter, R. (1969). Présence de Varanidae (Reptilia, Sauria) dans le Miocène de Catalogne. Considérations sur l'histoire de la famille. Bulletin du Muséum National d'Histoire Naturelle, 40, 1051-1064.

Holmes, R. B., Murray, A. M., Attia, Y. S., Simons, E. L., \& Chatrath, P. (2010). Oldest known Varanus (Squamata: Varanidae) from the Upper Eocene and Lower Oligocene of Egypt: Support for an African origin of the genus. Palaeontology, 53, 1099-1110.

Klembara, J. (1981). Beitrag zur Kenntnis der Subfamilie Anguinae (Reptilia, Anguidae). Acta Universitatis Carolinae, Geologica, 2, 121-168.

Klembara, J., \& Rummel, M. (2018). New material of Ophisaurus, Anguis and Pseudopus (Squamata, Anguidae, Anguinae) from the Miocene of the Czech Republic and Germany and systematic revision and palaeobiogeography of the Cenozoic Anguinae. Geological Magazine, 155, 20-44.

Kormos, T. (1911). A Polgárdi pliocén csontlelet. Földtani Közlöny, $41,48-64$.

Kotsakis, T. (1989). Late Turolian amphibians and reptiles from Brisighella (northern Italy): Preliminary report. Bollettino della Societa Palaeontologica Italiana, 28, 277-280.

Koufos, G. D. (2006). The Neogene mammal localities of Greece: Faunas, chronology, and biostratigraphy. Annales Géologiques des Pays Helléniques, 4, 183-214.

Koufos, G. D. (2012a). A new protictithere from the late Miocene hominoid locality Ravin de la Pluie of Axios Valley (Macedonia, Greece). Paläontologische Zeitschrift, 86, 219-229.

Koufos, G. D. (2012b). New material of Carnivora (Mammalia) from the Late Miocene of Axios Valley, Macedonia, Greece. Comptes Rendus Palevol, 11, 49-64.

Koufos, G. D. (2013). Neogene mammal biostratigraphy and chronology of Greece. In X. Wang, L. J. Flynn, \& M. Fortelius (Eds.), Fossil mammals of Asia. Neogene biostratigraphy and chronology (pp. 595-621). New York: Columbia University Press.

Laurenti, J. N. (1768). Specimen medicum, exhibens synopsin reptilium emendatam cum experimentis circa venena et antidota reptilium austracorum, quod authoritate et consensu. Vienna: Joan. Thomae nob. De Trattnern.

Lécuru, S. (1969). Etude morphologique de l'humérus des lacertiliens. Annales des Sciences naturelles, Zoologie et Biologie animale, 11, 515-558.

Linnaeus, C. (1758). Systema Naturae per regna tria naturae, secundum classes, ordines, genera, species, cum characteribus, differentiis, synonymis, locis. Stockholm: Laurentii Salvii.

Lungu, A. N., Zerova, G. A., \& Chkhikvadze, V. M. (1983). Primary evidence on the Miocene Varanus of the North Black Sea litoral. Bulletin of the Academy of Sciences of the Georgian SSR, 110, 417-420.

Malakhov, D. V. (2005). The early Miocene herpetofauna of Ayakoz (Eastern Kazakhstan). Biota, 6, 29-35.

Merceron, G., Blondel, C., Viriot, L., Koufos, G. D., \& de Bonis, L. (2007). Dental microwear analysis of bovids from the Vallesian (late Miocene) of Axios valley in Greece: Reconstruction of the habitat of Ouranopithecus macedoniensis (Primates, Hominoidea). Geodiversitas, 29, 421-433.

Merrem, B. (1820). Versuch eines systems der Amphibien (Vol. 8). Marburg: J. C. Krieger.

Miklas-Tempfer, P. M. (2003). The Miocene Herpetofaunas of Grund (Caudata; Chelonii, Sauria, Serpentes) and Mühlbach am Manhartsberg (Chelonii, Sauria, Amphisbaenia, Serpentes), Lower Austria. Annalen des Naturhistorischen Museums in Wien, 104A, 195-235. 
Młynarski, M. (1956). Lizards from the Pliocene of Poland. Part VI. Study of the Tertiary bone-breccia fauna from Węze near Działoszyn in Poland. Acta Palaeontologica Polonica, 1, 135-152.

Młynarski, M. (1964). Die jungpliozane Reptilienfauna von Rębielice Królewskie, Polen. Senckenbergiana biologica, 45, 325-347.

Młynarski, M., Szyndlar, Z., Estes, R., \& Sanchiz, B. (1984). Amphibians and reptiles from the Pliocene locality of Weze II near Działoszyn (Poland). Acta Palaeontologica Polonica, 29, 209-227.

Molnar, R. E. (2004). Part 2. The long and honorable history of monitors and their kin. In R. E. Pianka, D. King, \& R. A. King (Eds.), Varanoid lizards of the world (pp. 10-67). Bloomington: Indiana University Press.

Nopcsa, F. (1908). Zur Kenntnis der fossilen Eidechsen. Beitrage zur Paläontologie und Geologie Osterreich-ungarns und des Orients, 21, 33-62.

Nopcsa, F. (1923). Die Familien der Reptilien. Fortschritte der Geologie und Paläontologie, 2, 1-210.

Oppel, M. (1811). Die Ordnungen, Familien, und Gattungen der Reptilien als Prodrom einer Naturgeschichte derselben (p. 86). München: Joseph Lindauer.

Papp, A., Thenius, E., Berger, W., \& Weinfurter, E. (1953). Vösendorf-ein Lebensbild aus dem Pannon des Wiener Beckens. Ein Beitrag zur Geologie und Paläontologie der unterpliozänen Congerienschichten des südlichen Wiener Beckens. Mitteilungen der Geologischen Gesellschaft in Wien, 46, 1-109.

Pianka, R. E., King, D., \& King, R. A. (2004). Varanoid lizards of the world. Bloomington: Indiana University Press.

Rage, J.-C. (1984). Serpentes. In P. Wellnhofer (Ed.), Encyclopedia of paleoherpetology, part 11. Stuttgart: Gustav Fischer Verlag.

Rage, J.-C. (2013). Mesozoic and Cenozoic squamates of Europe. Palaeobiodiversity and Palaeoenvironments, 93, 517-534.

Rage, J.-C., \& Augé, M. (2003). Amphibians and squamate reptiles from the lower Eocene of Silveirinha (Portugal). Ciências da Terra (UNL), 15, 103-116.

Rage, J.-C., \& Bailon, S. (2005). Amphibians and squamate reptiles from the late early Miocene (MN 4) of Béon 1 (Montréal-duGers, southwestern France). Geodiversitas, 27, 413-441.

Rage, J.-C., \& Sen, S. (1976). Les Amphibiens et les Reptiles du Pliocène supérieur de Çalta (Turquie). Géologie méditerranéenne, 3, 127-134.

Rey, K., Amiot, R., Lécuyer, C., Koufos, G. D., Martineau, F., Fourel, F., et al. (2013). Late Miocene climatic and environmental variations in northern Greece inferred from stable isotope compositions $(\delta 18 \mathrm{O}, \delta 13 \mathrm{C})$ of equid teeth apatite. Palaeogeography, Palaeoclimatology, Palaeoecology, 388, 48-57.

Richter, A. (1995). The vertebrate locality Maramena (Macedonia, Greece) at the Turolian-Ruscinian Boundary (Neogene). 3. Lacertilia (Squamata, Reptilia). Münchner Geowissenchaften Abhandlungen, 28, 35-38.

Roger, O. (1898). Wirbelthierreste aus dem Dinotheriensande, II. Theil. Bericht des Naturwissenschaftlichen Vereins für Schwaben und Neuburg in Ausburg, 33, 385-396.

Russell, A. P., \& Bauer, A. M. (2008). The appendicular locomotor apparatus of Sphenodon and normal-limbed squamates. In C. Gans, A. S. Gaunt, \& K. Adler (Eds.), Biology of the reptilia: The skull and appendicular locomotor apparatus of
Lepidosauria, Volume 21, Morphology I (pp. 1-465). Ithaca: Society for the Study of Amphibians and Reptiles.

Sanz, J. (1977). Presencia de Varanus (Sauria, Reptilia) en el Plioceno de Layna (Soria). Trabajos sobre Neogeno-Cuaternario, $8,113-125$.

Schneider, B. (1975). Ein mittelpleistozäne Herpetofauna von der Insel Chios, Ägäis. Senckenbergiana biologica, 56, 191-198.

Smith, K. T., Bhullar, B.-A. S., \& Holroyd, P. A. (2008). Earliest African record of the Varanus stem-clade (Squamata: Varanidae) from the early Oligocene of Egypt. Journal of Vertebrate Paleontology, 28, 909-913.

Szyndlar, Z. (1985). Ophidian fauna (Reptilia, Serpentes) from the uppermost Miocene of Algora (Spain). Estudios Geológicos, 41, $447-465$.

Szyndlar, Z. (1991a). A review of Neogene and Quaternary snakes of Central and Eastern Europe. Part I: Scolecophidia, Boidae, Colubrinae. Estudios Geológicos, 47, 103-126.

Szyndlar, Z. (1991b). A review of Neogene and Quaternary snakes of Central and Eastern Europe. Part II: Natricinae, Elapidae, Viperidae. Estudios Geológicos, 47, 237-266.

Szyndlar, Z. (1995). The vertebrate locality Maramena (Macedonia, Greece) at the Turolian-Ruscinian Boundary (Neogene). 4. Serpentes (Squamata, Reptilia). Münchner Geowissenschaftliche Abhandlungen, Reihe A, 28, 35-39.

Szyndlar, Z. (2005). Snake fauna from the Late Miocene of Rudabánya. In: R. L. Bernor, L. Kordos, \& L. Rook (Eds.), Multidisciplinary research at Rudabánya. Palaeontographia Italica, 90, 31-52.

Szyndlar, Z. (2012). Early Oligocene to Pliocene Colubridae of Europe: A review. Bulletin de la Societe Geologique de France, 183, 661-681.

Szyndlar, Z., \& Rage, J.-C. (1990). West Palearctic cobras of the genus Naja (Serpentes: Elapidae): Interrelationships among extinct and extant species. Amphibia-Reptilia, 11, 385-400.

Szyndlar, Z., \& Rage, J.-C. (1999). Oldest fossil vipers (Serpentes: Viperidae) from the old World. Kaupia, 8, 9-20.

Szyndlar, Z., \& Rage, J.-C. (2002). Fossil record of the true vipers. In G. Schuett, M. Hoggren, M. Douglas, \& H. Greene (Eds.), Biology of the vipers (pp. 419-441). Eagle Mountain: Eagle Mountain Publishing.

Szyndlar, Z., \& Schleich, H. H. (1993). Description of Miocene snakes from Petersbuch 2 with comments on the lower and middle Miocene ophidian faunas of southern Germany. Stuttgarter Beiträge zur Naturkunde B, 192, 1-47.

Szyndlar, Z., \& Zerova, G. (1990). Neogene cobras of the genus Naja (Serpentes: Elapidae) of East Europe. Annalen des Naturhistorischen Museums in Wien, 91A, 53-61.

Venczel, M. (2006). Lizards from the Late Miocene of Polgárdi (W. Hungary). Nymphaea, Folia naturae Bihariae, 33, 25-38.

Wallach, V., Williams, K. L., \& Boundy, J. (2014). Snakes of the world: A catalogue of living and extinct species. Boca Raton: CRC Press.

Weithofer, A. (1888). Beiträge zur Kenntniss der Fauna von Pikermi bei Athen. Beiträge zur Paläontologie Österreich-Ungarns, 6, 225-292.

Zerova, G. A., \& Chkhikvadze, V. M. (1986). Neogene Varanids of the USSR. In Z. Roček (Ed.), Studies in Herpetology (pp. 689-694). Prague: Charles University of Prague. 